\title{
Stages of Faith From Infancy Through Adolescence: Reflections on Three Decades of Faith Development Theory
}

\author{
JAMES W. FOWLER \\ MARY LYNN Dell
}

$\mathrm{F}$

aith development theory was pioneered originally in the 1970s (Fowler, 1974) and 1980s (Fowler, 1981) as a framework for understanding the evolution of how human beings conceptualize God, or a Higher Being, and how the influence of that Higher Being has an impact on core values, beliefs, and meanings in their personal lives and in their relationships with others. Because of the formative influence of this theoretical work in both religious and spiritual development (including multiple references in this volume), it merits full articulation and a recounting of its origins. This chapter gives the early history of the author's faith development theory and introduces readers to its key concepts, with special emphasis on those stages most commonly seen in children and adolescents. It also reviews some of the critical and constructive assessments of faith development theory by scholars in the field, through the lenses of several volumes of collected articles.

\section{The Birth AND Nurture}

\section{of Faith Development Studies}

Harvard Divinity School in 1968 was a place where a diverse community of students studied

AUTHOR'S NOTE: Portions of this chapter are adapted from Fowler, J. W. (2004). Faith development at 30: Naming the challenges of faith in a new millennium. Religious Education, 99, 405-421, used by permission of the Religious Education Association; and from Fowler, J. W., and Dell, M. L. (2004). Stages of faith and identity: Birth to teens. Child and Adolescent Psychiatric Clinics of North America, 13, 17-34, used by permission of Elsevier. 
theology in the context of the bitterly dividing struggle in the United States over the Vietnam War. It was also a time when polarization in the civil rights movement had intensified. Against those backgrounds, I developed my first course for master's of divinity students out of my experiences at a retreat center called Interpreter's House (after the place in Pilgrim's Progress), and my interest in the kind of practical theology that attends to and expresses the human experiences of growth and of awakening to faith. I wanted students to honor the dynamics of doubt, as well as the formative faith experiences in their families and faith communities. I called that first course "Theology as the Symbolization of Experience." H. Richard Niebuhr and Paul Tillich provided theological starting points, which I correlated with readings from Erik Erikson, Robert Bellah, and a number of other social scientific sources. With a class of 40, I supplemented the twice-weekly class sessions by meeting with my students each week in four separate discussion groups of 10. In these weekly small gatherings, candid sharing among students took place, with me and each other, and in their wrestling with the texts we read. Many of them were deeply engaged by the moral challenges of the war in Vietnam, with the struggle for full civil rights for African Americans, and other pressing social justice issues.

Early in my teaching, students began to ask whether I knew the work of then new Harvard professor Lawrence Kohlberg. At Harvard's Graduate School of Education, Kohlberg was just establishing the Center for Moral Development, building on his research and development of the stage theory of moral development. I soon sought out Kohlberg's unpublished writings. Through our students, he and I met. His use of Jean Piaget's theory of cognitive development, along with his interview research and theory of moral development, complemented the work of Erikson and the theological figures I was teaching.

Under the influence of coming to know Kohlberg and the stimulating circle of younger investigators around him, in a year or two, I began to have my students conduct what we came to call faith development interviews. Using a questionnaire that we constructed, and eventually, a set of interpretation and analysis guidelines, we began to form the baseline data that would result in the construction and validation of what came to be known as faith development theory.

Among the blessings to my life and work in that period was the presence, in the early 1970s, of three Jesuits in their tertianship year in one of my courses. They sensed that my faith at this point was very cognitively oriented, and that my deeper needs for prayer and spirituality might not be being met. They introduced me to the Spiritual Exercises of Saint Ignatius. Eventually this led to my participating in a fruitful Nineteenth Annotation guided retreat, in the Ignatian tradition, under the leadership of Fr. Robert Doherty, S. J.

In the meantime, my ties to Kohlberg's circle at the Harvard Graduate School of Education grew and deepened. Carol Gilligan, Robert Selman, and eventually, Robert Kegan, and theologian educator Sharon Parks-along with many others-were formative in a rich environment of structural developmental studies. When the Joseph P. Kennedy, Jr. Foundation provided a substantial fund for faith development research, I formed a team of graduate students from theology and developmental psychology. For 3 years, along with my students, we conducted and analyzed the 359 interviews on which the stages of faith are based.

The growing influence of Kohlberg's theory of moral development and its pedagogical implications found strong acceptance in many Catholic schools across the nation and, indeed, the world. The educators who had claimed the structural development theory of Kohlberg, seeing its kinship to the natural law tradition, were primed to engage the emerging research and theory of faith development. This interest led to an invitation that would draw me into a 10-year relation with Boston College's Summer Institute for Religious Education and Pastoral Ministries, a program that drew hundreds of nuns, priests, and lay Catholic educators each year from the United States and across the world. The refinement, adoption, and dissemination of the emerging faith development theory greatly expanded through these Boston College connections. The invitation to write what became Stages of Faith and to publish it with Harper came in 1979, and was partly the result of my summer students 


\section{6 • FOUNDATIONS}

copying and sending the notes and handouts for the course to colleagues all over the world. In 1977, I had moved to Emory University's Candler School of Theology to teach and do research. There, with strong support for the faith development enterprise, I was able to complete Stages of Faith, which was published in 1981. The book is now in its 40th printing, if you count both the hardback and paperback editions.

\section{An Overview OF Faith Development Theory}

Faith development theory and research have focused on a generic understanding of faith that sees it as foundational to social relations, to personal identity, and to the making of personal and cultural meanings (Dell, 2000; Fowler, 1980, 1981, 1986a, 1986b, 1987, 1989, 1991, 1996). Like many dimensions of our lives, faith seems to have a broadly recognizable pattern of development. This unfolding pattern can be characterized in terms of developing emotional, cognitive, and moral interpretations and responses. Our ways of imagining and committing in faith correlate significantly with our ways of knowing and valuing more generally. We are asking you to think of faith in a more inclusive sense than Christian, Buddhist, Islamic, or Judaic faith. Faith, in the sense used here, even extends beyond religious faith. Understood in this more inclusive sense, faith may be characterized as an integral, centering process, underlying the formation of the beliefs, values, and meanings that:

1. Give coherence and direction to persons' lives;

2. Link them in shared trusts and loyalties with others;

3. Ground their personal stances and communal loyalties in a sense of relatedness to a larger frame of reference; and

4. Enable them to face and deal with the challenges of human life and death, relying on that which has the quality of ultimacy in their lives.

Faith, taken in this broad sense, is a common feature of human beings. In the language of child psychiatrist Erik Erikson, faith begins with basic trust, as the child forms bonds with the mother and other intimate caregivers. As the child matures, physically and emotionally, faith accommodates the development of an expanding range of object relations, and exposure to religious symbols and practices may nurture a sense of relatedness to the transcendent. We will draw on research, theory, and clinical observations that provide more detailed perspectives on the emergence and development of faith, understood in this broader sense, from birth through the teen years.

\section{Stages of Faith: An Overview}

In the following descriptions of the faith stages and the changes they bring, we acknowledge the complex interplay of factors that must be taken into account if we are to begin to understand faith development. These include biological maturation, emotional and cognitive development, psychosocial experience, and the role of religiocultural symbols, meanings, and practices. This complexity is increased if we consider gender and race, which we try to do in this account. Because development in faith involves all of these aspects, human developmentmovement from one stage to another-is not automatic or assured. Persons may reach chronological and biological adulthood while remaining best described by a structural stage of faith that would most commonly be associated with early or middle childhood, or adolescence. By the same token, contexts of spiritual nurture and practice, coupled with a person's spiritual aptitude and discipline, may lead some children to a deeper and more rapid development in faith.

\section{Primal Faith (Infancy to Age 2)}

More physical and neurological growth and development occurs in the first year of life than during any other life stage. Assuming a relatively uncomplicated pregnancy and delivery and a healthy neonate, parents can expect the birth weight to double by 5 months of age and triple by the first birthday. Length at birth will increase by $50 \%$ during the first year. By the second birthday the brain will attain $70 \%$ of its full adult weight, its neurons sprouting millions of dendrites. By 3 months of age infants can 
attend to visual and auditory stimuli for at least 3 to 5 seconds. By 16 weeks they can hold up their heads, and by 5 months they have developed characteristic arm and leg movements for contented and angry states. At 9 months, babies can gesture intentionally for desired objects or to be picked up. At 12 months, females are able to walk with support, with African American and other ethnicities mastering these gross motor skills earlier than many infants of European backgrounds. Females often achieve these physical milestones slightly earlier than males. By her first birthday she attains object permanence, the knowledge that an object continues to exist even when it is out of her immediate sight (Dell \& Dulcan, 1998; Zuckerman, Frank, \& Augustyn, 1999).

Attachment between the infant and her or his parent/caregiver is a process with important implications for the child's future relationships. Attachment refers to the emotional bond-begun at birth and nurtured for months thereafter - that is enduring, specific to the individual adult and infant combination, and that both stimulates, and is stimulated, by physical closeness. After the first successful attachment to the primary caregiver(s), the infant can generalize the ability to attach emotionally to select others. The first year is crucial in shaping the young child's ability to make healthy attachments in other relationships. For too many individuals, male and female, inadequate caregiving, abuse, and neglect adversely affect this vital process. In Erikson's framework, the developmental task of this time period is characterized as the development of a sense of basic trust (Erickson, 1963; Zuckerman et al., 1999).

In this first stage a prelanguage disposition of trust forms in the mutuality of one's relationships with parents and other caregivers. This sense of trust offsets the inevitable anxiety and mistrust that result from the succession of cognitive and emotional experiences of separation and self-differentiation, which occur during infant development. Experiences combining to form this trusting disposition include body contact and care; vocal and visual interplay; ritualized interactions associated with early play, feeding, and tending; and the development of interpersonal affective attunement in the infant's relations with caregivers. Factors such as these activate prepotentiated capacities for finding coherence and reliability in self and primal others, for forming bonds of attachment with them, and for shaping a disposition to trust the larger value and meaning commitments conveyed in parental care. Anxiety and mistrust have their own developmental pattern of emergence that caregivers' consistency and dependability help to offset (Erickson, 1963; Fowler, 1989, 1996; Stern, 1985).

\section{Intuitive-Projective Faith (Toddlerhood and Early Childhood)}

In young children, gross motor, fine motor, and cognitive development are intertwined processes related to the maturation timetables of the central and peripheral nervous systems. Neurons are migrating, proliferating, and making more complex connections. Children become capable of more sophisticated communications with the production of neurotransmitters. Myelination, the sheathing of neurons in protective layers of fatty and protein substances, increases the rate of neuronal firing and facilitates faster, more complex signals between brain cells and from the brain to the rest of the body. Good nutrition is crucial to these physiological processes, and early educational stimulation is increasingly appreciated for its role in activating certain neural pathways that might otherwise remain dormant or understimulated. The toddler and preschool periods are times of monumental brain development, continuing a young girl's or boy's susceptibility to physical and emotional neglect and abuse (Krug \& Mikus, 1999; Zigler \& Gilman, 1998).

Cognitively, the toddler is in transition between Piagetian stages. The last phase of the sensorimotor stage occurs in the first part of the 2nd year. Piaget's preoperational stage emerges in the 3rd year as she tries out symbolic thought and representational play. Toddlers are curious about other children, and progress from individual, solitary play (parallel play) to doing the same thing side by side, without significant interaction with each other (associative play). For Erikson, the fundamental issue of this stage is autonomy versus shame and doubt, and, if all goes well, the desired outcomes are the positive qualities of self-control and willpower (Dell \& Dulcan, 1998; Erickson, 1963; Krug \& Mikus, 1999; Lewis, 1997; Piaget, 1970, 1976).

From the time children begin to use language to communicate about self and objects in the 


\section{8 - FOUNDATIONS}

world, we see the emergence of a style of meaning making based on an emotional and perceptual ordering of experience. Imagination, not yet disciplined by consistent logical operations, responds to story, symbol, dream, and experience. Children attempt to form images that can hold and order the mixture of feelings and impressions evoked by their encounters with the newness of both everyday reality and the penumbra of mystery that surrounds and pervades it. Death becomes a conscious focus as a source of danger and mystery. Experiences of power and powerlessness orient children to a frequently deep existential concern about questions of security, safety, and the power of those on whom they rely for protection. Owing to naive cognitive egocentrism, children do not consistently differentiate their perspectives from those of others. Lacking simple perspective taking and the ability to reverse operations, young children may not understand cause-and-effect relations well. They construct and reconstruct events in episodic fashion. Fantasy and makebelieve are not distinguished from factuality. Constructions of faith are drawn to symbols and images of visible power and size. Stories that represent the powers of good and evil in unambiguous fashion are prized; they make it possible for children to symbolize and acknowledge the threatening urges and impulses that both fascinate and disturb them, while providing an identification with the vicarious triumphs of good over evil that such stories as fairy tales can provide (Bettelheim, 1977). There is in this stage the possibility of aligning powerful religious symbols and images with deep feelings of terror and guilt, as well as of love and companionship. Such possibilities give this stage the potential for forming deep and long-lasting emotional and imaginal orientations-both for good and for ill (Fowler, 1976).

\section{Mythic-Literal Faith (Middle Childhood and Beyond)}

By the 7th year, the brain has reached $90 \%$ of its adult weight, and the process of myelination is largely complete. Fine motor-adaptive skills and small-muscle control are refined as well, permitting elementary school children to tie their shoes easily, snap their fingers, and whistle. Girls and boys are close to the same height and weight until approximately age 10, with girls tending to experience the onset of pubertal changes an average of 2 years earlier than boys (Dell \& Dulcan, 1998).

Melvin Levine (1990) has outlined 12 "developmental missions" for a young person in middle childhood: (1) to sustain self-esteem; (2) to find social acceptance, primarily with peers; (3) to "reconcile individuality with conformity"; (4) to identify and emulate role models; (5) to examine values; (6) to feel successful in the family; (7) to explore the freedom and limits of autonomy; (8) to grow in knowledge and skill; (9) to become reconciled to his or her own body; (10) to handle fears; (11) to limit and control appetites and drives, including food, sexual drives, material wants, the seeking of attention; and (12) to "know thyself," or to develop self-awareness.

Although the emotive and imaginal funding of the previous stage is still operative in this newly emerging stage, concrete operational thinking (Piaget) makes possible more stable forms of conscious interpretation and shaping of experience and meanings. Operations of thought can now be reversed, which means that causeand-effect relations are more clearly understood. Simple perspective taking emerges, which ensures that the differentiation of one's own experiences and perspectives from those of others becomes a dependable acquisition. The young person constructs the world in terms of a new "linearity" and predictability. Although still a potent source of feelings, the previous stage's store of images may get "sealed over," and the episodic, intuitive forms of knowing that marked earlier childhood are subordinated to the use of capacities for more logical and prosaic modes of thinking (Piaget, 1970, 1976).

In the mythic-literal stage, the child, adolescent, or adult does not yet construct the interiority - the feelings, attitudes, and internal guiding processes - of the self or others. That is to say, 10-year-olds do not yet reliably have their feelings. They are involved in the process of learning to recognize, interpret, and manage strong feelings and impulses. Similarly, they do not construct God in particularly personal terms, or attribute to God highly differentiated internal emotions and interpersonal sensitivities. In making sense of the larger order of things, therefore, this stage typically structures the ultimate environment- the cosmic pattern of God's rule 
or control of the universe-along the lines of simple fairness and moral reciprocity. God is often constructed on the model of a consistent and caring, but just, ruler or parent. In this stage one often sees a sense of cosmic fairness at work: The child believes that goodness is rewarded and badness is punished.

In shaping meanings the mythic-literal child primarily employs narrative. In this respect, this stage provides a permanent contribution to meaning making. Stories are as close as the mythic-literal stage comes to reflective synthesis. Neither children nor adolescents (or adults) of this stage carry out extensive analytic or synthetic reflection on their stories. They offer narratives from the middle of the flowing streams of their lives. They do not "step out on the banks" to reflect on where the streams have come from, where they are going, or on what larger meanings might give connection and integrated intelligibility to their collection of experiences and stories. In this stage the use of symbols and concepts remains largely concrete and literal.

The mythic-literal stage begins to wane with the discovery that ours is not a "quick-payoff universe"; that is, evil or bad persons do not necessarily suffer for their transgressions, at least in the short run. And often, "bad things happen to good people." We have coined the term "11-year-old atheists" for children who, in having this latter experience, temporarily or permanently give up belief in a God built along the lines of simple cosmic moral retribution.

The mythic-literal stage initiates and develops the beginnings of reflection on the feelings and ideas of faith. It may be that girls, whom Carol Gilligan and others see as having an earlier and more developed interest in and vocabulary for interpersonal relatedness, progress more rapidly in an awareness of the emotions and skills of interpersonal relatedness. This can mean that girls may give attention to the dynamics of relationships earlier than do boys, bringing both greater sensitivity, on the one hand, and more ease in both managing and manipulating interpersonal relations, on the other (Gilligan, 1982).

\section{Synthetic-Conventional Faith (Adolescence and Beyond)}

Puberty (for girls) brings accelerated growth in height and weight, an increase in the percentage of overall body fat, and the emergence of secondary sexual characteristics. In addition it brings the menarche, usually beginning between 8 and 13 years of age. The average age for menarche in the United States among girls of European American ancestry is 12.9 years; among girls of African American descent it is slightly more than half a year earlier at 12.2 years (with a standard deviation of 1.2 years for both groups) (Ford \& Coleman, 1990; Neinstein, 1990; Offer, Schonert-Reichl, \& Boxer, 1996). For boys, on average, the comparable patterns of the onset of the bodily and emotional transformations of adolescence come a year or so later.

Accompanying the exploding physical, glandular, and sexual changes brought on by adolescence, the synthetic-conventional era also brings revolutions in cognitive functioning and interpersonal perspective taking. With the emergence of early formal operational thinking (Piaget), a young person's thought and reasoning take wings. Capable of using and appreciating abstract concepts, young persons begin to think about their own thinking, to reflect upon their stories, and to name and synthesize their meanings (Piaget, 1970, 1976).

In this period we see the emergence of mutual interpersonal perspective taking (Selman, 1974, 1976): "I see you seeing me; I see the me I think you see." And the obverse can also be appreciated: "You see you according to me; you see the you you think I see." This capacity can make youths acutely sensitive to the meanings they seem to have for others, and the evaluations those meanings imply. The lack of "third person" perspective taking, however, often makes the young teen overdependent on the responses and mirroring responses and evaluations of significant others. Identity and personal interiority-one's own and others'become absorbing concerns.

Personality, both as style and substance, becomes a conscious issue. From within this stage youth construct the ultimate environment in terms of the personal. God representations can be populated with personal qualities of accepting love, understanding, loyalty, and support during times of crisis. During this stage youths develop attachments to beliefs, values, and elements of personal style that link them in con-forming (formingwith) relations with the most significant others 


\section{0 - FOUNDATIONS}

among their peers, family, and other nonfamily adults. Identity, beliefs, and values are strongly felt, even when they contain contradictory elements. They tend, however, to be espoused in tacit, rather than explicit, formulations. At this stage one's ideology or worldview is lived and asserted; only gradually does it become a matter of critical and reflective articulation.

Where earlier deficits in the self and in one's patterns of object relations have not been worked through and healed, they become factors that can inhibit the use of cognitive abilities in the tasks of identity and ideology construction in adolescence. Frequently we see splits between the emotional and cognitive functioning of adolescents or adults that are directly attributable to such unresolved issues and relations from early childhood. Sometimes the potential of God as a constructive self-object must be jettisoned because God can only be emotionally populated with the shaming or narcissistic qualities growing out of our experiences with our earliest and most salient object relations.

One decisive limit of the synthetic-conventional stage is its lack yet of third-person perspective taking - a lack of the capacity to construct and work from a perspective that holds both self and other in the same frame, and provides a basis for growing objectivity regarding interpersonal relationships. This means that in its dependence on significant others for confirmation and clarity about one's identity and meaning to them, the synthetic-conventional self does not yet have a third-person perspective from which it can see and evaluate self-other relations from a viewpoint outside themselves. In the synthetic-conventional stage the young person or adult can remain trapped in the "Tyranny of the They" - that is, an overdependence on the mirroring and evaluations of influential significant others.

\section{The Later Stages of Faith}

In order to place faith stages typically encountered in childhood and adolescence in context with the trajectory of growth that may be experienced in young, middle, and older adulthood, readers may find somewhat less detailed explanations of the final three stages of faith development theory helpful. In addition, we recognize that many professionals not only work with parents and other adults significant in the lives of children, but continue clinical work with adult patients and thus may be interested in the entire theory from birth through the end of life.

As one considers faith development theory in general, and especially the final three stages, it is important to bear in mind three points.

First, by determining which stage an individual may be operating from at any given time, we are in no way assigning a grade to or judgment about the validity, sincerity, value, or effectiveness of that individual's relationship to the deity of his or her faith. To identify a person's stage or stage transition does not imply that his or her spiritual life is better, more faithful, or desirable than anyone else's, whether in that stage or another. Faith development theory is not intended to be used, nor should it ever be used, as a measure of "how good a Christian," "how good a Jew," "how good a Muslim," or "how good" anyone of any faith tradition may be. Making such judgments constitutes a major abuse of this theory. We are not putting a value judgment on the contents of a person's faith and religious/spiritual identity. We are attempting to describe patterns of knowing and relating through assessing cognitive, moral, and other forms of development that constitute a person's relationship to the transcendent or the Higher Being of a particular religious tradition and relationships with other humans, both inside and outside a person's particular faith community.

Second, with each successive stage comes a series of qualitatively distinguishable patterns of thought, realizations, and behaviors, and in each stage qualitatively new and more complex operations and capacities are added to those of the preceding stage(s).

Third, transition from one stage to another is not inevitable or assumed. For instance, although many elementary school-age children are best described by the mythic-literal stage, so are many adolescents and some adults. While there are no upper age limits to these stages, there are minimum ages below which the later stages are not normally found. For instance, it is unlikely for an individual to meet the description of the synthetic-conventional stage before the early teens or early adolescent years, and it is rare to see someone fully grounded in the individuative-reflective stage prior to the early 
20s. On the other hand, one can see individuals much older than the minimum ages experiencing transitioning into a next stage. And it is not unusual for many not to reach the later stages. Again, this does not constitute a value judgment on the maturity, sincerity, or worth of any individual's religious faith (Fowler, 1981, 1987).

\section{Individuative-Reflective Faith}

Two significant indicators mark the individuative-reflective stage. First, one must develop the ability to reflect critically on the values, beliefs, and commitments one subscribed to as part of constructing the previous stage, the synthetic-conventional. This reexamination of deeply held beliefs can be a painful process. Second, one must struggle with developing a self-identity and self-worth capable of independent judgment in relation to the individuals, institutions, and worldview that anchored one's sense of being up until that time. Questions representative of this stage include: Who am I when I am not defined primarily as someone's daughter, son, or spouse? Who am I apart from my educational, occupational, or professional identity? Who am I beyond my circle of friends or familiar community? In constructing the individuative-reflective position, inherited or familiar symbols, creeds, beliefs, traditions, and religious trappings are scrutinized, and those of other faiths and traditions may be evaluated for what they might have to offer. This testing applies, as well, to secular value systems, worldviews, and the circles that espouse them. In the end, the familiar and traditional beliefs and practices may not be rejected or discarded, but if they are retained, they are held with more selfaware clarity and intentional choice (Fowler, 1981, 1987).

\section{Conjunctive Faith}

The conjunctive stage is characteristic of a reflective adult thinker who recognizes that truths of all kinds can be approached from multiple perspectives and that faith must balance and maintain the tensions between those multiple perspectives. This stage makes sense out of paradoxes. In Christianity, for instance, God is seen as all-powerful and yet God limits the divine expression of power in granting humans agency and freedom. And though the sovereign of history, God took on the humble and lowly form of a human man who permitted himself to be put to death at the hands of other humans. This knowledge and faith build on necessary paradox and tensional, complex trust and commitment.

Individuals in the conjunctive stage express a principled interest in and openness to truths of other cultural and religious traditions, and believe that dialogue with those different others may lead to deepened understandings and new insights into their own traditions and beliefs. Other paradoxes that are dealt with in this stage include the realities that one is both old and young, with both masculine and feminine qualities, conscious and unconscious, and intentionally constructive and well meaning while at the same time being unintentionally destructive in some aspects of life and community membership. One is both singular and individuated, yet has an increased awareness of being dependent on and in interdependent solidarity with both friends and strangers. This results in the desire for new ways to relate to God, others, and self (Fowler, 1981, 1987).

\section{Universalizing Faith}

In this review of faith stages, we note that the circle of "people who count" has in each stage expanded, so that by the time one reaches the universalizing stage, one is concerned about creation and being as a whole, regardless of nationality, social class, gender, age, race, political ideology, and religious tradition. In this ultimate stage of faith, the self is drawn out of its own self-limits into a groundedness and participation in one's understanding of the Holy. Those once seen as enemies may be understood also to be children of God and deserving of unconditional love. Evil of all kinds is opposed nonviolently, leading to activism that attempts to change adverse social conditions as an expression of that universal regard for all life that emanates from God's love and justice.

While persons of universalizing faith continue to be human, with common shortcomings and inconsistencies, they are exceptional in the strength of their passion that all creation should manifest God's goodness and that all humanity be one in peace. In their boldness to live out the 


\section{2 • FOUNDATIONS}

convictions of their faith, they are both freeing and threatening to the rest of us. Relatively few individuals claim this level of vision and faithrelated action. Among those exceptional figures most would agree manifested or manifest the universalizing stage are Mohandas Gandhi, Mother Teresa, the Reverend Dr. Martin Luther King Jr., and, perhaps some would say, former U.S. president Jimmy Carter, Archbishop Desmond Tutu, and anti-death penalty activist Sister Helen Prejean (Fowler, 1981, 1987).

\section{Stages of Faith: The Effort to Be Inclusive}

Faith development theory bridges the categories of specific religions. Wilfred Cantwell Smith (1979), a great scholar in the interpretations of the world's religious traditions, set forth a succinct characterization of faith:

Faith, then, is a quality of human living. At its best it has taken the form of serenity and courage and loyalty and service: a quiet confidence and joy which enable one to feel at home in the universe, and to find meaning in the world and in one's own life, a meaning that is profound and ultimate, and is stable no matter what may happen to oneself at the level of immediate event. Men and women of this kind of faith face catastrophe and confusion, affluence and sorrow, unperturbed; face opportunity with conviction and drive; and face others with cheerful charity. (p. 12)

Smith contrasts faith with other terms that are frequently used as synonyms for faith: religion and belief. He finds that, closely studied, most of the major world traditions see faith not just as a matter of believing or of adhering to the teachings of a religious tradition. Rather, he says, "faith involves an alignment of the heart or will, a commitment of loyalty and trust" (p. 11). His explication of the Hindu term for faith, sraddha, puts it best: "It means, almost without equivocation, 'to set one's heart on.' To set one's heart on someone or something requires that one has 'seen' or 'sees the point of' that to which one is loyal" (p. 11). Faith is a resting of the heart, the investing of trust in and loyalty to a Reality or Being or Power (Fowler, 1981). Smith points out that the Hebrew (aman he'min, munah), the Greek (pistuo, Pistis), and the Latin (credo, credere) words for faith parallel those from the Buddhist, Muslim, and Hindu sources (Fowler, 1981; Selman, 1976).

\section{Significant Discussions of Faith Development Theory and Research}

There have been four collections of writings in which commentators and critics of faith development research and theory have written on the topic. ${ }^{1}$ [Author: PLEASE CONFIRM THAT THE NOTE PRECEDING THE REFERENCES IS THE ONE TO BE CITED HERE] The first appeared in 1980 and was initiated by Dr. Christiane Brusselmans, a religious educator from the Catholic University of Leuven, Belgium. She, with her colleagues at Leuven, and with the Harvard developmentalists Lawrence Kohlberg, James Fowler, and Robert Kegan, convened a conference in the 12th-century Cistercian Abbaye d'Senanque in the south of France in 1979. This conference brought together an international group of scholars, principally from Belgium, Switzerland, Ireland, and the United States. It included Protestants, Catholics, and Jews. The collection of essays from that fruitful conference was published as Toward Moral and Religious Maturity (Brusselmans, 1980).

The second collection of writings was edited by Professor Craig Dykstra, then on the faculty of Princeton Theological Seminary, and Dr. Sharon Daloz Parks, then a professor at Harvard Divinity School. With the support and hospitality of President Barbara Wheeler of the Auburn Theological Seminary in New York, Professors Dykstra and Parks convened a group of 13 professors of theology, psychology, and religious education in New York to present papers that provided constructive criticism and suggestions in critical engagement with faith development theory and research. A striking theme in this conference grew out of the intentional inclusion of feminist voices in commenting and proposing alternatives to faith development theory, based on gender studies and women's theological voices. The conference took place in 1982; its proceedings were published in 1986 as Faith Development and Fowler (Dykstra \& Parks, 1986).

A third collection of writings that critically engaged with faith development theory took 
form under the editorship of Dr. Jeff Astley of the North of England Institute for Christian Education and Dr. Leslie Francis of Trinity College, Carmarthen, Wales. Unlike its predecessors, this volume did not result from a conference. Rather, the editors drew together a set of Fowler's writings along with commentaries and critical articles on faith development by other authors from the United States and the United Kingdom, many of which had been published previously in journals. The majority of the authors were religious educators and scholars from developmental studies (Astley \& Francis, 1992).

The fourth volume of critical commentary was primarily prepared by and for European scholars, though it was translated for Englishspeaking readers as well. Edited by Karl Ernst Nipkow and Friedrich Schweitzer of the University of Tübingen, the essays in this volume placed faith development theory alongside the work on religious development of the Swiss scholar Fritz K. Oser, whose research in the structural developmental tradition of Jean Piaget has strong empirical grounding, particularly in relation to the study of children and youth. Oser wrote to inform the teaching of religion in Swiss and other European schools and schools (Fowler, Nipkow, \& Schweitzer, 1991). Both Fowler and Oser owe debts of gratitude to Lawrence Kohlberg as well as Jean Piaget. In this volume, some of the most penetrating commentary on the background and criticism of structural developmental theories comes from Nipkow and Schweitzer, from Clark Power of the University of Notre Dame, and from Nicola Slee of Rohampton Institute, Whitelands College, England. From the standpoint of religious education, Gloria Durka of Fordham University, Gabriel Moran of New York University, and John W. Hull of the University of Birmingham (England) provided trenchant insights.

\section{A Critical Issue in the Discussion of Faith Development Theory}

The most central divider between those who endorse faith development with few reservations and those who have some strong critical resistance lies, I believe, in the effort of faith development theory to define faith in a functional and structural form that can be inclusive of the dynamics of faith in many traditions, and even for some persons or groups who hold secular ideologies. Those who embrace the use of structural developmental trajectories, with their focus on different levels of cognitive, moral, and emotional operations, generally find the research and stage theory helpful in addressing questions of readiness and of matching educational methods. They find that the scaffolding the theory offers is also helpful in shaping the educational aims involved in teaching and exploring faith traditions. They acknowledge and assert-as I do-that the substantive contents of faith traditions, with their scriptures, liturgies, ethical teachings, and visions of the Holy, do provide strong, distinctive, and unique elements for religious formation. The "structuring power" of the substantive contents of faith makes a tremendous impact on the perceptions, motives, visions, and actions of believers. The stage theory makes its contribution, however, by helping to match the competences of each stage - and the operations of mind and emotion that characterize them-with ways of teaching and with the symbols, practices, and contents of faith at different levels of reflective inquiry and complexity. Educators of this mind-set find faith development theory helpful for preparing persons to teach at different age and stage levels, and to match their methods and communicative practices with the groups' probable stage or range of stages.

On the other hand, there are those who, for theological reasons, hold faith to be unique and particular to the Christian or to another specific religious tradition. For them, faith is not generic, and it is not definable apart from the contents and the practices of particular traditions. In his first article in the volume Faith Development and Fowler (Dykstra \& Parks, 1986), Dykstra (1986a) engages in a close argument in which he objects to distinguishing the structuring and functioning of faith from the substance, content, and practices of Christian faith. It pleases me, however, that later in that same volume, Dykstra (1986b) provides a strong and clear account of the usefulness of the stage theory for helping to guide and check the appropriate levels of teaching and curriculum for persons based on their structural stage-if the structuring power of the contents of a faith 


\section{4 - FOUNDATIONS}

tradition is not excluded or treated as interchangeable with that of other traditions or secular orientations.

This issue is an important one, and it should be made clear that the structuring power of the contents of religious faith traditions- the teachings, scriptures, practices, and ethical orientations, with their substance and power-are never to be ignored in the use of faith development theory. It should never be the primary goal of religious education simply to precipitate and encourage stage advancement. Rather, paying attention to stage and stage advancement is important in helping us shape our teaching and involvement with members of religious traditions. Movement in stage development, properly understood, is a by-product of teaching the substance and the practices of faith.

\section{Conclusions}

In closing, some of the strengths, limitations, and criticisms of faith development theory need to be acknowledged. Fortunately, the formative sample of 359 interviews was almost equally balanced at 50\% from each gender. In the original sample Protestants made up $45 \%$ of the interviewees, Catholics represented 36.5\%, $11.2 \%$ were Jews, and $3.6 \%$ were Orthodox Christians. A remaining $3.6 \%$ were "other." Given the growth in the numbers of adherents to other major traditions in the United States, interview research needs to be conducted to widen the sample to include Muslim, Buddhist, and secular respondents. Interviewees have not been studied longitudinally.

Further, most of the foundational research was conducted in the 1970s and 1980s. Subsequent research in the early 1990s largely confirmed the theory. Professor Heinz Streib of the University of Bielefeld is presently conducting the most significant research in the faith development tradition. The research he and his colleagues are carrying out in Europe and in the United States promises to yield considerable tangible new data and insights into these issues.

A new major round of faith development interviews could shed light on the impacts on people's faith of "globalization" and of the features of experience that have come to be called the "postmodern condition." Both of these phenomena reflect patterns of radical secularization and the erosion of religious and moral authority, on the one hand, and, paradoxically, the worldwide growth of fundamentalist and conservative faith practices, on the other. Add to these factors the rise in interest of many "nonreligious" persons in "spirituality," and one begins to grasp the richness and diversity that faith development research encounters today.

Note

1. A recent, thoughtful collection of essays by international authors critically engaging this author's work in faith development and practical theology is Osmer and Schweitzer (2003).

\section{REFERENCES}

Astley, J., \& Francis, L. (Eds.). (1992). Christian perspectives on faith development. Leominster, UK: Gracewing; Grand Rapids, MI: Eerdmans.

Bettelheim, B. (1977). The uses of enchantment: The meaning and importance of fairy tales. New York: Vintage.

Brusselmans, C. (Ed.). (1980). Toward moral and religious maturity. Morristown, NJ: Silver Burdett.

Dell, M. L. (2000). She grows in wisdom, stature, and favor with God: Female development from infancy through menarche. In J. Stevenson-Moessner (Ed.), In her own time (pp. 117-143). Minneapolis, $\mathrm{MN}$ : Fortress.

Dell, M. L., \& Dulcan, M. K. (1998). Childhood and adolescent development. In A. Stoudemire (Ed.), Human behavior: An introduction for medical students (3rd ed., pp. 261-317). Philadelphia: Lippincott-Raven.

Dykstra, C. (1986a). What is faith? An experiment in the hypothetical mode. In C. Dykstra \& S. D. Parks (Eds.), Faith development and Fowler (pp. 45-64). Birmingham, AL: Religious Education Press.

Dykstra, C. (1986b). Faith development and religious education. In C. Dykstra \& S. D. Parks (Eds.), Faith development and Fowler (pp. 251-271). Birmingham, AL: Religious Education Press.

Dykstra, C., \& Parks, S. D. (Eds.). (1986). Faith development and Fowler. Birmingham, AL: Religious Education Press. 
Erikson, E. H. (1963). Childhood and society (2nd ed.). New York: Norton.

Ford, C. A., \& Coleman, W. L. (1990). Adolescent development and behavior: Implications for the primary care physician. In M. D. Levine, W. B. Carey, \& A. C. Crocker (Eds.), Developmental and behavioral pediatrics (3rd ed., pp. 71-72). Philadelphia: Saunders.

Fowler, J. W. (1974). Agenda toward a developmental perspective on faith. Religious Education, 69, 209-219.

Fowler, J. (1980). Faith and the structuring of meaning. In C. Brusselsmans (Ed.), Toward moral development and religious maturity (pp. 58-81). Morristown, NJ: Silver Burdett.

Fowler, J. W. (1981). Stages of faith. New York: HarperCollins.

Fowler, J. W. (1984). Becoming adult, becoming Christian: Adult development and Christian faith. San Francisco: Harper and Row. (Revised edition published by Jossey-Bass, 2000)

Fowler, J. W. (1986a). Faith and the structuring of meaning. In C. Dykstra and S. D. Parks (Eds.), Faith development and Fowler (pp. 15-42). Birmingham, AL: Religious Education Press.

Fowler, J. W. (1986b). Dialogue toward a future in faith development studies. In C. Dykstra and S. D. Parks (Eds.), Faith development and Fowler (pp. 275-301). Birmingham, AL: Religious Education Press.

Fowler, J. W. (1987). Faith development and pastoral care. Philadelphia: Fortress Press.

Fowler, J. W. (1989). Strength for the journey: Early childhood development in selfhood and faith. In D. Blazer (Ed.), Early childhood and the development of faith (pp. 1-36). Kansas City, MO: Sheed and Ward.

Fowler, J. W. (1991). Weaving the new creation: Stages of faith and the public church. New York: HarperCollins.

Fowler, J. W. (1996). Faithful change: The personal and public challenges of postmodern life. Nashville, TN: Abingdon.

Fowler, J. W., Nipkow, K. E., \& Schweitzer, F. (Eds.). (1991). Stages of faith and religious development. New York: Crossroad.

Gilligan, C. (1982). In a different voice. Cambridge, MA: Harvard University Press.

Krug, E. F., \& Mikus, K. C. (1999). The preschool years. In M. D. Levine, W. B. Carey, \& A. C.
Crocker (Eds.), Developmental and behavioral pediatrics (3rd ed., pp. 38-50). Philadelphia: Saunders.

Levine, M. D. (1990). Middle childhood. In M. D. Levine, W. B. Carey, \& A. C. Crocker (Eds.), Developmental and behavioral pediatrics (3rd ed., pp. 51-67). Philadelphia: Saunders.

Lewis, M. (1997). Overview of infant, child, and adolescent development. In J. M. Wiener (Ed.), Textbook of child and adolescent psychiatry (2nd ed., pp. 44-56). Washington, DC: American Psychiatric Press.

Neinstein, L. S. (1990). Menstrual problems in adolescents. Medical Clinics of North America, 74, 1181-1182.

Offer, D., Schonert-Reichl, K. A., \& Boxer, A. M. (1996). Normal adolescent development: Empirical research findings. In M. Lewis (Ed.), Child and adolescent psychiatry: A comprehensive textbook (2nd ed., p. 280). Baltimore: Williams and Wilkins.

Osmer, R. R., \& Schweitzer, F. L. (Eds.). (2003). Developing a public faith: New directions in practical theology. St. Louis, MO: Chalice Press.

Piaget, J. (1970). Piaget's theory. In P. Mussen (Ed.), Carmichael's manual of child psychology, (3rd ed., vol. 1). New York: John Wiley and Sons.

Piaget, J. (1976). The child and reality. New York: Penguin.

Selman, R. L. (1974). The developmental conceptions of interpersonal relations. Boston: HarvardJudge Baker Social Reasoning Project.

Selman, R. L. (1976). Social-cognitive understanding: A guide to educational and clinical practice. In T. Lickona (Ed.), Moral development and behavior (pp. 299-316). New York: Holt, Rinehart and Winston.

Smith, W. C. (1979). Faith and belief. Princeton, NJ: Princeton University Press.

Stern, D. N. (1985). The interpersonal world of the infant. New York: Basic Books.

Zigler, E. F., \& Gilman, E. D. (1998). Day care and early childhood settings. Child and Adolescent Psychiatric Clinics of North America, 7, 483-498.

Zuckerman, B. S., Frank, D. A., \& Augustyn, M. (1999). Infancy and toddler years. In M. D. Levine, W. B. Carey, and A. C. Crocker (Eds.), Developmental and behavioral pediatrics (3rd ed., pp. 24-36). Philadelphia: Saunders. 